DOI https://doi.org/10.18551/rjoas.2018-11.15

\title{
THE EFFECT OF ORGANIZATIONAL JUSTICE ON JOB SATISFACTION AND IMPACT ON TURNOVER INTENTION
}

\author{
Dewi Ida Ayu Anggia Wedya*, Supartha I Wayan Gede \\ Management Program, University of Udayana, Bali, Indonesia \\ E-mail: anggiawedyadewi@yahoo.co.id
}

\begin{abstract}
This study was conducted to determine the effect of distributive justice, procedural justice, and interactional justice on employee job satisfaction and turnover intention at Batan Waru Restaurants Lippo Mall Kuta. The study was conducted on employees Batan Waru by the number of respondents as many as 42 employees. The test results distributive justice positive and significant impact on employee satisfaction, procedural fairness positive and significant impact on employee satisfaction, interactional fairness positive and significant effect on employee satisfaction. Distributive justice negative and significant impact on turnover intention, procedural fairness negative and significant impact on turnover intention, interactional fairness negative and impact on turnover intention, employee satisfaction negative and significant impact on turnover intention. The limitation of this study is the location of this research will be in the scope of the restaurant industry in Batan Waru Lippo Mall, Kuta, so the results of this study cannot explain the circumstances of the other restaurants besides restaurants Batan Waru Lippo Mall, Kuta.
\end{abstract}

\section{KEY WORDS}

Distributive justice, procedural justice, interactional justice, job satisfaction, turnover intention.

Turnover intention can be interpreted as an employee's intention to leave the organization, either in the form of resignation or dismissal. With high turnover, it can cause an organization to be less effective because of the loss of experienced employees (Andini, 2006). Previous research from Yucel (2012) on 250 manufacturing company employees in Turkey stated that if job satisfaction is high and turnover intention is lower, then there is a negative influence on job satisfaction on turnover intention. The same thing was stated by Alniacik et al. (2011) and Syahronica et al (2015) that job satisfaction has a negative relationship to turnover intention. Therefore a company is required to be able to retain its employees, such as being able to provide high remuneration and understand things that are able to make its employees comfortable and enthusiastic in working.

Job satisfaction is one of the employees' attitudes that has become a lot of research material that is associated with organizational justice. The biggest challenge faced by companies is how to retain competent employees. Job satisfaction is needed to produce functional employee behavior in the company. For companies, employee job satisfaction means they are motivated and committed to achieving high performance. Job satisfaction is an evaluation that describes a person feeling happy or unhappy, satisfied or dissatisfied at work (Rivai and Jauvani, 2009).

Cropanzo et al. (2002) stated that organizational justice is a key factor in understanding employee attitudes and behavior in an organization. Job satisfaction is one of the variables most often used in organizational behavior (Arti et al., 2009). Some studies have found results that organizational justice influences job satisfaction. Al'zubi (2010) conducted research with objects on employees of the Electrical Industrial Companies and the result was distibutive justice, procedural justice, and interactional justice had a positive and significant effect on job satisfaction. In line with the research, Elamin and Alomaim (2011) also obtained the same results when conducting research on local employees and outside employees working in different organizations in Saudi Arabia, that organizational justice has a positive effect on job satisfaction. In line with the study, Bakhshi et al. (2009), Memarzadeh and 
Mahmoudi (2010), and Al-Zu'bi (2010) also obtained the same results when conducting research with these variables.

Cropanzano et al. (2007) states that there are three main reasons why employees care about this justice problem. First, long-term benefits, employees prefer consistent justice, because with that justice employees can predict the results that will be obtained in the future. Employees also want to receive unfavorable rewards as long as the payment process they feel fair and get dignified treatment. Second, social considerations, everyone expects to be accepted and appreciated by their superiors not in a rude and unexploited manner. Third, ethical considerations, people believe that justice is a morally appropriate way to treat someone.

\section{LITERATURE REVIEW}

Justice Theory. This theory suggests that a person will feel satisfied and dissatisfied, depending on the presence or absence of justice (Equity) in a situation especially the work situation. The justice theory has been successfully used in explaining various forms of attitudes and behaviors at various levels in an organization. There are three main dimensions in organizational justice, namely distributive justice, procedural justice and interactional justice (Colquitt, 2001: 390). The first dimension is distributive justice related to the distribution of resource allocation and decision outcomes, for example about salary provision, incentives and rewards. The second dimension, procedural justice focuses on the process used to determine the outcome of decisions, such as promotion procedures, collecting information before making decisions, and terminating employment. The three interactional justice focuses on employees' perceptions of interpersonal treatment from leaders conducted during the representation of procedures and decisions, for example leaders can provide explanations.

Distributive Justice. Distributive justice is related to the perception of fairness about organizational allocation and outcomes (Saunders et al., 2002). Distributive justice is a perception of fairness in the ratio of the results of contributions to employees and comparison of ratios with other members of the organization (Adams, 1965). Distributive justice refers to perceived justice from the results received by individuals from the organization (Al'zubi, 2010). Distributive justice involves a comparison of salaries, benefits, promotions, power, rewards, and satisfaction (Rai, 2013).

Procedural Justice. Procedural justice is related to the perception of fairness in the use of processes, procedures and methods in making decisions (Thibaut and Walker, 1975). According to Robbin and Judge (2008) procedural justice is perceived justice from the process used to determine the distribution of benefits. According to Noe et al. (2011) procedural justice is a justice concept that focuses on the methods used to determine the rewards received. This mechanism is considered reasonable to the extent that they are consistent, accurate, correct, and ethical (Leventhal, 1980). Procedural justice is an embodiment of accepted normative principles such as consistency of procedures for offering compensation, consistency of regulations, avoiding personal interests in the distribution process, timeliness, and ethics (Badawi, 2012).

Interactional Justice. Interactional justice is defined as the interpersonal quality that people receive when procedures are applied and results are distributed (Bies and Moag, 1986). According to Robbins and Judge (2008), interactional justice is defined as an individual's perception of the degree to which an employee is treated with dignity, attention and respect. Interactional justice focuses on the individual on interpersonal treatment received from the leader, two important elements of the perception of interactional justice, namely whether the reasons underlying the resource allocation decision are clear and honest and can provide an explanation to the affected individuals (Kadaruddin et al., 2012). The same treatment in the workplace is considered as one of the most fundamental rights of employees (Svensson and Genugten, 2013).

Job satisfaction. McShane and Von Glinow (2008) stated that job satisfaction is an individual's evaluation of the task and the context of his work. According to Martoyo (2007: 
156) job satisfaction is an emotional state of employees where there is no meeting point between employee compensation from a company or organization and the level of return for services that is indeed desired by the employee concerned. According to Ardana et al. (2009: 23) Job satisfaction is the difference from something that should exist with something that is actually there (factual), the smaller the difference in conditions that should exist with the actual conditions (factual) someone tends to feel more satisfied. Bakhshi, et al. (2009) stated that job satisfaction is one of the variables most widely used in organizational justice research.

Turnover Intention. Behavioral and behavioral intentions such as absenteeism, exit, and rejection are often grouped into withdrawal. Tett and Meyer (1993) state that intention to exit is conscious awareness and desire to leave the organization. It can be described as a psychological response to the particular conditions of the organization that move along the continuum rather than just imagining going out of the organization until it actually physically leaves the organization. Hom and Griffeth (1991) define intention as the possibility that the employee predicts that he has consciousness and intentionally wants to permanently leave the organization at some time. Jaros (1997) states that exit intention is seen as an employee's affective commitment to the organization. Employees who are not committed and not bound by their work prefer to leave the organization. This is an important factor to determine the quality of individual contributions, and especially its productivity.

Hypotheses:

$\mathrm{H}_{1}$ : Distributive justice has a positive and significant effect on job satisfaction;

$\mathrm{H}_{2}$ : Procedural justice has a positive and significant effect on job satisfaction;

$\mathrm{H}_{3}$ : interactional justice has a positive and significant effect on job satisfaction;

$\mathrm{H}_{4}$ : Distributive justice has a negative and significant effect on turnover intention;

$\mathrm{H}_{5}$ : Procedural justice has a negative and significant effect on turnover intention;

$\mathrm{H}_{6}$ : Interactional justice has a negative and significant effect on turnover intention;

$\mathrm{H}_{7}$ : Job satisfaction has a negative and significant effect on turnover intention.

\section{METHODS OF RESEARCH}

The population in this study was 42 Batan Waru Lippo Mall Restaurant employees. The sampling technique uses a census method that involves all members of the population. Census methods may be used because the population is relatively small and the data obtained is more complete because it reflects the nature of the whole population. The number of questionnaires sent is 42 to all employees, with a return rate of $100 \%$ or return entirely. . Saturated or census sample method is used if all populations are used as respondents. The sample used is the entire population that is used as a sample so that the number of samples in this study was 42 people. Data analysis in this study used Partial Least Square (PLS) approach. PLS is an equation model for Structural Equation Modeling (SEM) based on components or variants. PLS is almost like a regression but more than that, it simultaneously combines the Structural Path model (the theoretical relationship between latent variables) while measuring the path (the relationship between the latent variable and the indicator).

\section{RESULTS AND DISCUSSION}

Model valuation with PLS begins by looking at R-square for each dependent latent variable. Changes in R-square values can be used to assess the effect of certain exogenous latent variables on endogenous latent variables that have substantive influence. Table 5.10 shows the results of R-square estimation using Smart PLS.

Table 1 - R-Square

\begin{tabular}{|c|c|}
\hline Variable & R Square \\
\hline Job satisfaction & 0,864 \\
\hline Turnover Intention & 0,937 \\
\hline
\end{tabular}

Primary Data, 2018. 
Table 1 shows the R-square construct value of employee job satisfaction of 0.864 in Table 5.9 can be interpreted that $86.40 \%$ construct variability of employee job satisfaction is explained by the construct of distributive justice, procedural justice and interactional justice, while $13.60 \%$ is explained by variables outside model. Likewise, the turnover intention construct with $\mathrm{R}$ square value of 0.937 means that $93.70 \%$ of the variability is explained by distributive justice, procedural justice, interactional justice, and job satisfaction, while $6.30 \%$ is explained by variables outside the model.

The basis used in testing hypotheses is the value found in the output for inner weight. Table 2 provides estimated outputs for structural model testing.

Table 2 - Result for Inner Weight

\begin{tabular}{|c|c|c|c|c|}
\hline Hypotheses & Original Sample (O) & T Statistics (|O/STERR|) & P Values & Description \\
\hline $\mathrm{H} 1$ & 0.373 & 3.382 & 0.001 & Accepted \\
\hline $\mathrm{H} 2$ & 0.317 & 2.952 & 0.003 & Accepted \\
\hline $\mathrm{H} 3$ & 0.295 & 2.720 & 0.007 & Accepted \\
\hline $\mathrm{H} 4$ & -0.172 & 1.988 & 0.047 & Accepted \\
\hline $\mathrm{H} 5$ & -0.183 & 2.558 & 0.011 & Accepted \\
\hline $\mathrm{H} 6$ & -0.325 & 4.190 & 0.000 & Accepted \\
\hline $\mathrm{H} 7$ & -0.341 & 3.049 & 0.002 & Accepted \\
\hline
\end{tabular}

Source: Primary data, 2018.

The effect of Distributive Justice on Job Satisfaction. The results of testing the first hypothesis shows that distributive justice influence on satisfaction shows the path coefficient value of 0.373 with a $P$ Value of 0.001 significance value or $P$ Value of 0.001 is much smaller than 0.05 indicating that there is a positive and significant influence between the variables of distributive justice and satisfaction. The path coefficient shows that distributive justice has a positive and significant effect on satisfaction, meaning that the better the distributive justice perceived by the employee, the job satisfaction will increase.

The effect of procedural justice on job satisfaction. The results of the third hypothesis testing show that the influence of procedural fairness on satisfaction shows the path coefficient value of 0.317 with a $P$ Value of 0.003 . The significance value or $P$ value of 0.003 is much smaller than 0.05 , indicating that there is a positive and significant influence between procedural justice variables on satisfaction. The path coefficient shows that procedural justice has a positive and significant influence on satisfaction, meaning that the better procedural justice perceived by employees, the more job satisfaction will increase.

The effect of Interactional Justice on Job Satisfaction. The fifth hypothesis testing results show that the effect of interactional justice on satisfaction shows the path coefficient value of 0.295 with a $P$ Value of 0.007 . significance value or $P$ Value of 0.007 far smaller than 0.05 indicates that there is a positive and significant influence between the variables of interactional justice on satisfaction. The path coefficient shows that interactional justice has a positive and significant influence on satisfaction, meaning that the better interactional justice perceived by employees, the more job satisfaction will increase.

The effect of Distributive Justice on Turnover Intention. The results of the second hypothesis testing show that the effect of distributive justice on turnover intention shows the path coefficient value of -0.172 with a $P$ Value of 0.047 . significance value or $P$ Value of 0.047 smaller than 0.05 indicates that there is a negative and significant influence between distributive justice and turnover intention variables, meaning that as good as the distributive justice perceived by employees, the lower the intention of the employee to leave the company.

The effect of Procedural Justice on Turnover Intention. The fourth hypothesis test results show that the influence of procedural justice on turnover intention shows the path coefficient value of -0.183 with a $P$ Value of 0.011 . Significance value or $P$ Value of 0.011 is much smaller than 0.05 indicating that there is a negative and significant influence between procedural justice variables on turnover intention. The path coefficient shows that procedural justice has a negative and significant effect on turnover intention, meaning that the better the 
distributive justice perceived by the employee, the smaller the intention of the employee to leave the company.

The effect of Interactional Justice on Turnover Intention. The test results of the sixth hypothesis show that the effect of interactional justice on turnover intention shows the path coefficient value of -0.325 with a $P$ Value of 0.000 . the significance value or $P$ Value of 0.000 is much smaller than 0.05 indicating that there is a negative and significant influence between the variables of interactional justice on turnover intention. The path coefficient shows that interactional justice has a negative and significant influence on satisfaction, meaning that the better interactional justice perceived by employees, the smaller the intention of the employee to leave the company.

The effect of Satisfaction on Turnover Intention. The results of testing the intended hypothesis indicate that the effect of satisfaction on turnover intention shows the path coefficient value of -0.341 with a $P$ Value of 0.002 . significance value or $P$ Value of 0.002 is much smaller than 0.05 indicating that there is a negative and significant influence between satisfaction variables on turnover intention. The path coefficient shows that satisfaction has a negative and significant influence on turnover intention, meaning that the more employees feel satisfied, the smaller and the intention of the employee to leave the company.

\section{CONCLUSION AND SUGGESTIONS}

Based on the results of the analysis of the research conducted in CHAPTER $V$, the conclusions are obtained as follows:

- Distributive justice has a positive and significant effect on the job satisfaction of Batan Waru Lippo Mall restaurant employees. This influence means that the better the distributive justice felt by employees, the better the job satisfaction felt by Batan Waru Lippo Mall restaurant employees;

- Procedural justice has a positive and significant effect on the job satisfaction of Batan Waru Lippo Mall restaurant employees. This means that the better procedural fairness felt by employees, the better the job satisfaction felt by Batan Waru Lippo Mall restaurant employees;

- Interactional justice has a positive and significant effect on the job satisfaction of Batan Waru Lippo Mall restaurant employees. This means that the better interactional justice that employees feel, the better the job satisfaction felt by Batan Waru Lippo Mall restaurant employees;

- Distributive justice has a negative and significant effect on Batan Waru Lippo Mall restaurant staff turnover intention. This influence means that the higher the level of distributive justice perceived by employees, the lower the desire of employees to leave the company;

- Procedural justice has a negative and significant effect on Batan Waru Lippo Mall restaurant employee turnover intention. This influence means that the higher the level of procedural fairness, the lower the desire of employees to leave the company;

- Interactional justice has a negative and significant effect on Batan Waru Lippo Mall restaurant employee turnover intention. This influence means that the higher the level of interactional justice, the lower the desire of employees to leave the company;

- Job satisfaction has a negative effect on turnover intention. This means that the higher the employee feels job satisfaction, the lower their desire to leave the company.

Based on the results of the study, here are some suggestions that can be used as a consideration for the management of Batan Waru Restaurant in determining future policies, especially those relating to distributive justice, procedural justice, interactional justice, job satisfaction, and turnover intention.

Organizations must pay more attention to distributive factors, the allocation of contributions to employees, such as paying attention to the benefits received by employees must reflect the effort given by employees in their work. Referring to respondents' 
perceptions of procedural fairness, namely fairness in the use of processes, procedures, and methods in making decisions, management is expected to pay attention to matters such as allowing employee unions to oversee the application of regulations in the company.

Referring to respondents' perceptions of interactional justice that is about the degree to which an employee is treated with dignity, attention and respect. It is hoped that management will pay more attention to matters such as procedures for treating employees with dignity so that each employee can feel valued in his workplace. Referring to respondents' perceptions of job satisfaction, it is suggested that management can improve job satisfaction through providing rewards that are in accordance with the contributions that have been given by employees to the company, giving employees the opportunity to express their opinions, treating employees with dignity and management so refrain from saying inappropriate to employees so that it can improve employee job satisfaction.

Referring to employees' perceptions of turnover intention, the management was suggested to be able to overcome and provide solutions to the level of employee desire to quit their job and find another job. As for if the management is able to overcome and resolve problems - problems faced by employees will have an impact on increasing employee job satisfaction and automatic turnover intention will be lower.

Subsequent research is suggested to enrich the findings of the study to examine the role of other variables that influence job satisfaction and are influenced by job satisfaction. In the research location, researchers only researched in restaurants located in Kuta, so it was suggested that further research could expand the orientation in the scope of a larger organization or wider population.

Research Limitations:

- This study uses respondents who are in the restaurant service industry, so it is important for future research to complement and enrich empirical studies related to this topic by conducting research on other service companies;

- This study was only carried out in one restaurant so that the results of this study might not be applied in other restaurants that have the same problems or the results of this study cannot be generalized to similar service sector companies or other sectors;

- The scope of research is limited to the Kuta area, so the results of this study cannot be generalized to research outside the Kuta area.

\section{REFERENCES}

1. Adams, S. J. (1965). "Inequity in Social Exchange". in Advances in Experimental Social Psychology, pp: 269-297

2. Alniacik, Umit. Ersan Cigerim. Kultigin Akcin. Orkun Bayram .(2011). Independent and joint effects of perceived corporate reputation, affective commitment and job satisfaction on turnover intentions.Procedia Social and Behavioral Sciences 24.1177-1189.

3. Andini, Rita. 2006. Analisis Pengaruh Kepuasan Gaji, Kepuasan Kerja, Komitmen Organisasional Terhadap Turnover Intention (Studi Kasus Pada Rumah Sakit Roemani Muhammadiyah Semarang). Tesis. Program Studi Magister Manajemen Universitas Diponogoro.

4. Badawi. (2012). Peran Emosi Memediasi Keadilan Distributif, Keadilan Prosedural, and Interaksional Terhadap Kepuasan Pemulihan Layanan. Jurnal Manajemen and Akuntansi. Vol. 1(1), h: 13-26

5. Bakhshi, A., Kumar, K., \& Rani, E. 2009. Organizational Justice Perceptions as Predictor Of Job Satisfaction And Organization Commitment. International Journal of Business and Management, Vol. 4, No. 9, pp. 145-154.

6. Bies, R.J. (2005). Are Procedural Justice \& Interactional Justice Conceptually Distinct?, Handbook Of Orgnizational Justice. Lawrence Erlbaum Associates, Inc.

7. Bakotic, Danica; and Babic, Tomislav. 2013. Relationship between Working Condition and Job Satisfaction: The Case of Croatian Shipbuilding Compani. International Journal of Business and Social Science. 4(2), pp: 206-212. 
8. Chen, Zhen Xiong., and Anne Marie Francesco. (2000). Employee Demography, Organizational Commitment, and Turnover Intentions in China: Do Cultural Difference Matter?. Human Relations Vol. 53 No. 6: 869-887.

9. Colquitt, J.A. (2001). On The Dimensionality Of Organizational Justice: A Construct Validation Of Measure. Journal of Applied Psychology, Vol. 86 (3), pp. 386-400.

10. Cropanzo, R., Bowen, D. E., \& Gilliland, S. W. (2007). The management of organizational justice. The Academy of Management Perspectives, 21(4), 34-48.

11. Cropanzano, Russell, Cynthia A. Prehar and Peter Y. Chen. (2002). Using Social Exchange Theory to Dstinguish Procedural from Interactional Justice. Group \& Organizational Management. Vol. 27 (3), pp: 324-351.

12. Elamin, Abdallah M. and Alomaim Nasser (2011). Does Organizational Justice Influence Job Satisfaction and Self-Perceived Performance in Saudi Arabia Work Environment? International Management Review, Vol. 7(1)

13. Hom, P.W. et al, 1984. The Validity of Mobby"s (1977) Model of Employee Turnover. Organizational Behavior \& Human Performance, Vol. 34, pp. $141-174$

14. Hom, P.W. \& Griffeth, R.W. 1991. Structural Equation Modelling Test of a Turnover Theory: Cross-Sectional \& Longitudinal Analysis. Journal of Applied Psychology, Vol. 76, No. 3, pp. 350-366.

15. Jaros, S.J. 1997. An Assessment of Meyer and Allen"s (1991) Three-Component Model Of Organizational Commitment Turnover Intentions. Journal Of Vocational Behavior, Vol. 51 , pp. $319-337$

16. Kumar, R., Charles, R., and Peter Y. 2011. A Study on Turnover Intention in Fast Food Industry: Employees' $F$ it to the Organizational Culture and the Important of their Commitment. International Journal of Academic Research in Business and Social Sciences, 2 (5), pp: 9-42

17. Martoyo, Susilo. 2007. Manajemen Sumber Daya Manusia. Edisi Kelima. BPFEYogyakarta.

18. McShane, S.L. \& Von Glinow, M.A. 2008. Organizational Behavior: Emerging Realities for The Workplace Revolution, 4th Edition, McGrawHill/Irwin.

19. Nadiri, Halil., and Tanova, Cem. 2010. An Investigation Of The Role Of Justice In Turnover Intentions, Job Satisfaction, And Organizational Citizenship Behavior In Hospitality Industry. International Journal Of Hospitality Management. 29, pp: 33-41

20. Noe, R.A., Hollenbeck, J.R., Gerhart, B., \& Wright, P.M. (2011). Manajemen Sumber Daya Manusia: Mencapai Keunggulan Bersaing, Edisi 6. Penerbit Salemba Empat.

21. Rai, G. S. (2013). Impact of organizational justice on satisfaction, commitment and turnover intention: Can fair treatment by organizations make a difference in their workers' attitudes and behaviors? International Journal of Human Sciences, 10(2), 260-284

22. Robbins, S.P. (2008). Perilaku Organisasi, Edisi 2. Penerbit Salemba Empat.

23. Saunders, M. N. K., Thornhill, A., \& Lewis, P. (2002). Understanding employees' reactions to the management of change: an exploration through an organizational justice framework. Irish Journal of Management, 23(1), 85-108

24. Svensson, Jorgen and Marieke van Genugten. (2013). Retaliation Againts Reporters of Unequal Treatment: Failing Employee Protection In The Netherlands. Equality, Diversity and Inclusion An International Journal. Vol. 32 (2), pp: 129-143.

25. Tett, R.P. \& Meyer, J.P. 1993. Job Satisfaction, Organizational Commitment, Turnover Intention, \& Turnover: Path Analyses Based On Meta - Analytic Findings. Personnel Psychology, Vol. 46, pp. 259 - 293.

26. Thibaut, J. W. \& Walker, L. (1975). Procedural justice: A psychological analysis. Hillsdale, $\mathrm{NJ}$ : Lawerence Eribaus Associates.

27. Yucel, Ilhami. 2012. Examining the Relationship among Job Satisfaction, Organizational Commitment, and Turnover Intention: An Empirical Study. International Journal of Business and Management, 7(20), pp: 44-58. 